\title{
HIGH DISCHARGE RATE ELECTRODEPOSITED ZINC ELECTRODE FOR USE IN ALKALINE MICROBATTERY
}

\author{
A.L. NOR HAIRIN ${ }^{1}$, RAIHAN OTHMAN ${ }^{2}$, MOHD HANAFI ANI ${ }^{1}$ AND HENS SAPUTRA ${ }^{3}$ \\ ${ }^{I}$ Department of Manufacturing and Materials Engineering, \\ ${ }^{2}$ Department of Science in Engineering, \\ Faculty of Engineering, International Islamic University Malaysia, \\ P.O. Box 10, 50728 Kuala Lumpur, Malaysia. \\ ${ }^{3}$ Pusat Teknologi Industri Proses, \\ Badan Pengkajian dan Penerapan Teknologi (BPPT), \\ Jl. M.H. Thamrin No. 8, Jakarta 10340, Indonesia.
}

raihan@iium.edu.my

\begin{abstract}
High discharge rate zinc electrode is prepared using the electrodeposition process. The electrolytic bath consists of zinc chloride as the metal source and ammonium chloride as the supporting electrolyte. The concentration of the supporting electrolyte is varied from zero until $4 \mathrm{M}$, while the concentration of zinc chloride is fixed at $2 \mathrm{M}$. The aim is to produce a porous zinc coating with an enhanced and intimate interfacial area per unit volume. These characteristics shall contribute towards reduced ohmic losses, improved active material utilization, and subsequently producing high rate capacity electrochemical cell. Nitrogen physisorption at $77 \mathrm{~K}$ is used to measure the BET surface area and pore volume density of the zinc electrodeposits. The electrodeposited zinc electrodes are then fabricated into alkaline zinc-air microbattery measuring $1 \mathrm{~cm}^{2}$ area $\mathrm{x}$ ca. $305 \mu \mathrm{m}$ thick. The use of inorganic MCM-41 membrane separator enables the fabrication of a compact cell design. The quality of the electrodeposited zinc electrodes is gauged directly from the electrochemical performance of zinc-air cell. Zinc electrodeposits prepared from electrolytic bath of $2 \mathrm{M} \mathrm{NH}_{4} \mathrm{Cl}$ produces the highest discharge capacity.
\end{abstract}

ABSTRAK: Elektrod zink dengan kadar discas tinggi telah dihasilkan dengan proses saduran elektrokimia. Takungan elektrolit terdiri daripada zink klorida sebagai sumber logam dan ammonium klorida sebagai elektrolit sokongan. Kepekatan elektrolit sokongan diubah daripada sifar hingga $4 \mathrm{M}$, sementara kepekatan zink klorida ditetapkan pada $2 \mathrm{M}$. Ini bertujuan untuk mendapatkan saduran zink yang poros dengan luas permukaan per unit isipadu dan sentuhan antaramuka yang dipertingkatkan. Ciri-ciri ini akan menyumbang terhadap pengurangan kehilangan disebabkan kerintangan, pertambahan dalam gunapakai bahan aktif dan akhirnya menghasilkan sel elektrokimia berprestasi tinggi. Physisorpsi nitrogen pada $77 \mathrm{~K}$ telah digunakan untuk mengukur luas permukaan BET dan isipadu liang saduran zink. Saduran zink kemudiannya dijadikan elektrod bagi bateri mikro zink-udara beralkali dengan saiz $1 \mathrm{~cm}^{2}$ luas x ca. $305 \mu \mathrm{m}$ tebal. Penggunaan membran tak organik MCM-41 membolehkan pembuatan sel dengan rekabentuk padat. Kualiti elektrod saduran zink telah dinilai secara lansung daraipada prestasi elektrokimia sel zink-udara. Saduran zink yang disediakan daripada takungan elektrolit $2 \mathrm{M} \mathrm{NH}_{4} \mathrm{Cl}$ menghasilkan kapasiti discas tertinggi.

KEYWORDS: zinc electrodeposition; high discharge rate electrode; MCM-41 separator; zinc-air cell; alkaline microbattery 


\section{INTRODUCTION}

Electrodeposition is one of the most commonly practiced industrial techniques for the fabrication of zinc coatings [1-3]. It is an effective and fast technique to obtain a coating of desired material for a variety of applications. The thickness of the coating can easily be controlled and even the material properties can be pre-designed. Thus, zinc electrodeposition has been extensively investigated under various operating conditions depending on the application considered or the aims chosen. Variety of applications of zinc coating include as corrosion protective coating, to provide decorative surface layers for materials, to alter the technological properties of materials, and to reduce cost of materials [4-6].

In this work, zinc electrodeposits are prepared from an acidic chloride bath of various electrolytic formulations. The aim is to produce a porous zinc coating with an enhanced and intimate interfacial area per unit volume. These characteristics shall contribute towards reduced ohmic losses, improved active material utilization, and subsequently producing high rate capacity zinc anode for use in alkaline cell, in particular zinc-air microbattery. Though there were numerous work done on properties of zinc coatings and mostly utilizing cyclic voltammetry as the main tool [7-9], our approach is to gauge the electrodeposited zinc anode directly from the performance of the electrochemical cell.

\section{EXPERIMENTAL}

\subsection{Electrolytic Cell and Bath Formulation}

A two-electrode configuration electrolytic cell was adopted for the electrodeposition process. The working electrode was zinc foil $(99.9 \%)$ and the counter electrode was copper foil. Both electrodes were mounted on a home-made acrylic board clamp with an exposed square window $(1 \mathrm{~cm} \times 1 \mathrm{~cm})$ for electrodeposition area. The electrode spacing was fixed at $30 \mathrm{~mm}$. The bath formulation composed of zinc chloride $\left(\mathrm{ZnCl}_{2}\right)$ as the metal source and ammonium chloride $\left(\mathrm{NH}_{4} \mathrm{Cl}\right)$ as the supporting electrolyte. The concentration of the supporting electrolyte was varied from 1 to $4 \mathrm{M}$, while the concentration of zinc chloride was fixed at $2 \mathrm{M}$. Total electrolyte volume was maintained at $80 \mathrm{ml}$. During electrodeposition no electrolyte agitation was attempted.

Electrodeposition was performed at a constant current of 0.1 A for duration of 1.5 hours. An EcoChemie (The Netherland) potentiostat/galvanostat (PGSTAT302N, AUTOLAB) was used.

\subsection{Physical Characterization of Zinc Electrodeposits}

Nitrogen physisorption gas chromatography was utilized to measure the BET surface area and pore volume density of the zinc electrodeposits. The sorption isotherms of nitrogen at $77 \mathrm{~K}$ were determined in a pressure range $\mathrm{p} / \mathrm{p}^{0}$ from 0.001 to slightly below 1.0. An AUTOSORB-1 (QUANTACHROME) instrumentation was used.

\subsection{Fabrication of Zinc-Air Cell and Electrochemical Characterizations}

Zinc electrodeposits prepared from all electrolytic bath formulations were used as the anode and assembled into zinc-air cell. Compact, planar zinc foil was also utilized for reference purposes. A commercially available air electrode sheet was utilized as the cathode. The air electrode consisted of laminated fibrous carbon structure supported by a nickel mesh. The airside of the electrode is covered with semi permeable hydrophobic Teflon membrane to permit air access. We employed inorganic MCM-41 membrane as the 
cell separator. It also served as the electrolyte reservoir due to its porous nature and hydrophilic property. MCM-41 membrane was applied onto the electrodeposited zinc anode by dip-coating technique. Details on the membrane preparation and its properties can be referred to the work of Saputra and co-workers [10]. The cell electrolyte was $6 \mathrm{M}$ potassium hydroxide $(\mathrm{KOH})$. Figure 1 illustrates the as-synthesized zinc-air cell structure and its dimensions.

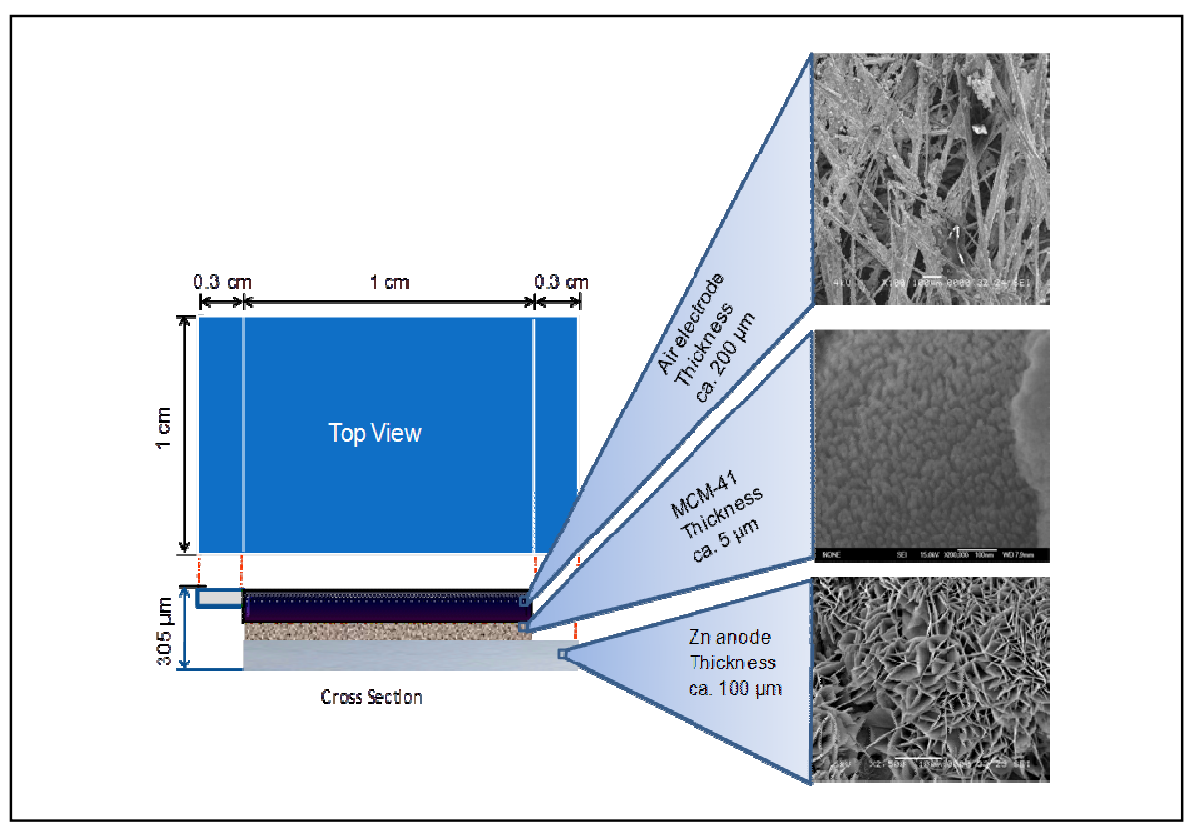

Fig. 1: As-synthesized zinc-air cell structure.

Zinc-air cells utilizing the electrodeposited zinc anode were characterized according to the polarization profile, power density output and galvanostatic discharge performance. The aim was to evaluate directly various qualities of zinc electrodeposits from the electrochemical cell performance.

\section{RESULTS AND DISCUSSION}

Table 1 highlights the results of the nitrogen physisorption measurement i.e. the BET surface area and pore volume density of the zinc electrodeposits. Firstly, note that the deposition spot was $1 \mathrm{~cm} \times 1 \mathrm{~cm}$ square area. Thus considering $0.25 \mathrm{~mm}$ zinc foil used as the working electrode as an example, and considering zinc density of $7.14 \mathrm{~g} \mathrm{~cm}^{-3}$, the apparent specific surface area of the zinc foil is $0.056 \mathrm{~m}^{2} \mathrm{~g}^{-1}$. By using electrodeposition method, the specific surface area of zinc coatings is now more than $300 \mathrm{~m}^{2} \mathrm{~g}^{-1}$ which clearly demonstrates the advantage of electrodeposition method. Electrolytic bath with 3$\mathrm{M} \mathrm{NH}_{4} \mathrm{Cl}$ produced zinc electrodeposits with the highest specific surface area i.e. $379 \mathrm{~m}^{2}$ $\mathrm{g}^{-1}$. On the other hand, electrolytic bath formulation with $2 \mathrm{M}-\mathrm{NH}_{4} \mathrm{Cl}$ produced the most porous zinc electrodeposits i.e. with pore volume density of $0.227 \mathrm{~cm}^{3} \mathrm{~g}^{-1}$ which is equivalent to $62 \%$ porosity.

Figure 2 illustrates the polarization profiles of zinc-air cell employing the electroplated zinc anode. The profile of zinc-air cell utilizing a compact, planar zinc foil as anode is also shown. Cells employing electroplated zinc anode showed superior profiles, in particular the high discharge rate capability. Using compact zinc foil, the limiting 
IIUM Engineering Journal, Vol. 12, No. 5, 2011: Special Issue on Science and Ethics in Engineering Nor Hairin et al.

current of the cell was $13 \mathrm{~mA}$ and the value markedly increased to more than $50 \mathrm{~mA}$ (i.e. between $52-55 \mathrm{~mA}$ ) when electroplated zinc anode was utilized. Limiting current is the

Table 1: BET surface area and pore volume density of zinc electrodeposits as a function of $\mathrm{NH}_{4} \mathrm{Cl}$ content.

\begin{tabular}{|c|c|c|c|c|}
\hline \multicolumn{3}{|c|}{ Electrolytic Bath Composition } & \multirow{3}{*}{$\begin{array}{l}\text { BET Surface Area } \\
\left(\mathrm{m}^{2} / \mathrm{g}\right)\end{array}$} & \multirow{3}{*}{$\begin{array}{l}\text { Pore Volume Density } \\
\qquad\left(\mathrm{cm}^{3} / \mathrm{g}\right)\end{array}$} \\
\hline \multirow{2}{*}{$\begin{array}{c}\mathrm{ZnCl}_{2} \\
(\mathrm{~g} / \mathrm{L}) \\
(2 \mathrm{M})\end{array}$} & \multicolumn{2}{|c|}{$\mathrm{NH}_{4} \mathrm{Cl}$} & & \\
\hline & $(\mathrm{g} / \mathrm{L})$ & $\begin{array}{c}\text { Molarity } \\
\text { (M) }\end{array}$ & & \\
\hline 273.0 & 0 & 0 & 351.37 & 0.211 \\
\hline 273.0 & 53.5 & 1 & 349.61 & 0.2216 \\
\hline 273.0 & 107.0 & 2 & 350.69 & 0.2273 \\
\hline 273.0 & 160.5 & 3 & 379.54 & 0.2215 \\
\hline 273.0 & 214.0 & 4 & 331.93 & 0.2108 \\
\hline
\end{tabular}

maximum discharge current that can be supplied by a cell prior to an abrupt voltage drop. For zinc-air cell the abrupt drop occurs when the operating voltage reaches the value around $0.8-0.9 \mathrm{~V}$. The highest limiting current obtained was from zinc electrodeposits of $3 \mathrm{M}-\mathrm{NH}_{4} \mathrm{Cl}$ bath i.e. $55 \mathrm{~mA}$. Though the difference between the highest and lowest limiting current density value seems small, i.e. $3 \mathrm{~mA}$, note that the cell size was $1 \mathrm{~cm} \mathrm{x} 1$ $\mathrm{cm}$. If the apparent cell area is increased by ten times for example to $33 \mathrm{~mm} \times 33 \mathrm{~mm}$, then the anticipated difference of $30 \mathrm{~mA}$ would be quite substantial. Figure 3 depicts the corresponding power output density plot of the cells obtained from polarization profiles of Fig. 2. Power output of the cell was measured from the product of discharge current and the subsequent operating voltage. By using electroplated zinc anode, the maximum power density output was enhanced from $13 \mathrm{~mW} \mathrm{~cm}^{-2}$ to $55 \mathrm{~mW} \mathrm{~cm}^{-2}$, a fourfold increment. 
IIUM Engineering Journal, Vol. 12, No. 5, 2011: Special Issue on Science and Ethics in Engineering Nor Hairin et al.

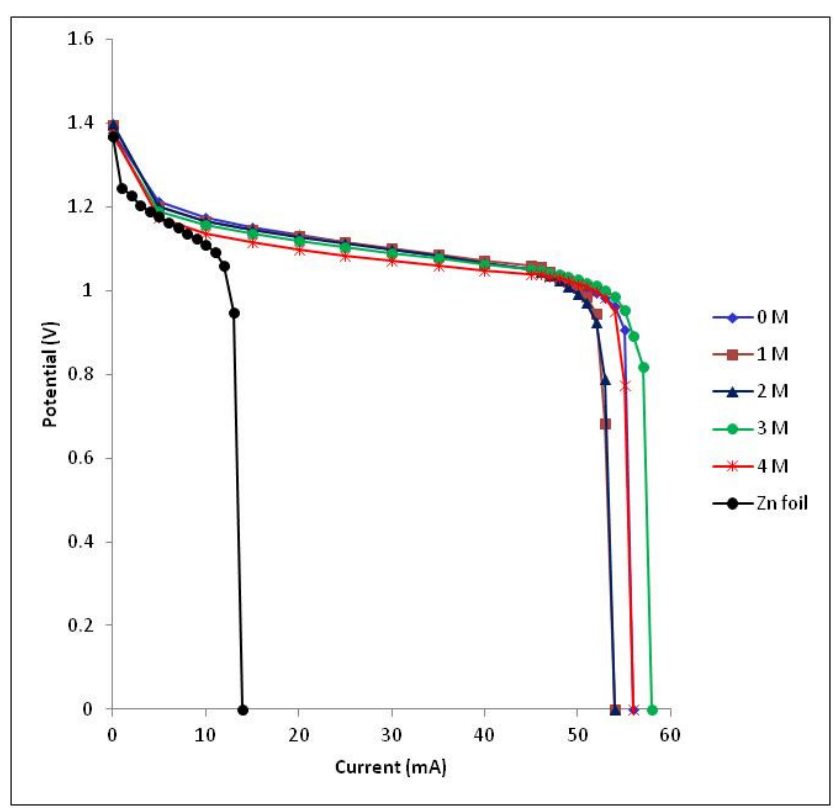

Fig. 2: Polarization profiles of zinc-air cell. 


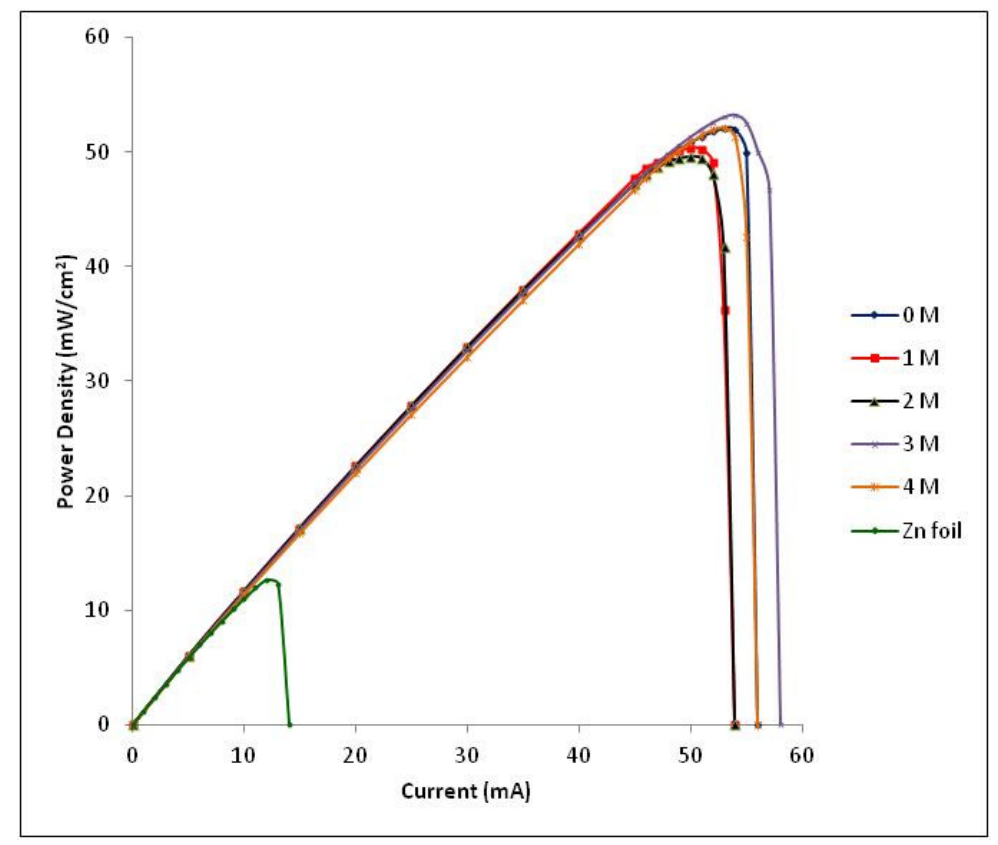

Fig. 3: Power output density plot of zinc-air cell.

Figure 4 illustrates the discharge capacity performance of zinc-air cells utilizing electroplated zinc anode of various electrolytic formulation. The cells were rated at $20 \mathrm{~mA}$ of constant discharge load. Cell employing compact zinc foil could not be discharged at 20 $\mathrm{mA}$ load, refer to Fig. 2 of the polarization profile for cell using compact zinc foil as the anode. The discharge curves of Fig. 4 denote the distinct profile of zinc-air cell; a flat discharge curve with an abrupt voltage drop at the end of discharge [11]. This is mainly attributed to the fact that as the electropositive oxygen reactant is not stored within the electrochemical system, the changes in the internal resistance of the cell is small thus producing a rather flat discharge profile [12]. The cell utilizing zinc electrodeposits of 2 $\mathrm{M}-\mathrm{NH}_{4} \mathrm{Cl}$ electrolytic bath produced the highest discharge capacity of $34.5 \mathrm{mAh}$ i.e. 2 hour 15 min discharge duration.

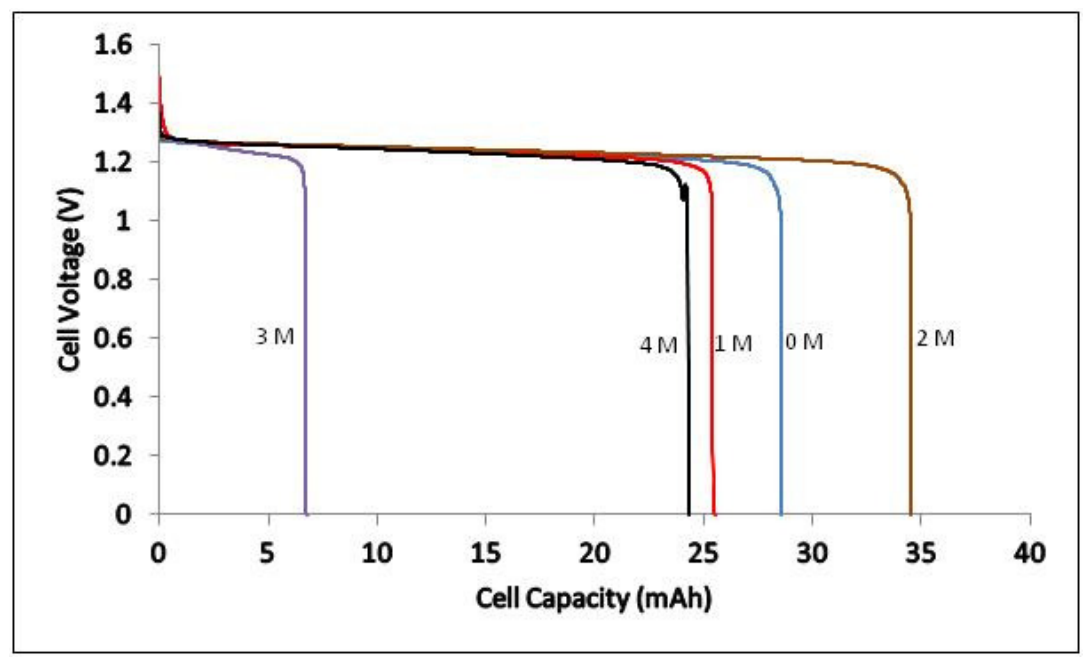

Fig. 4: Discharge capacity of zinc-air cell employing electrodeposited zinc anode of various electrolytic bath formulations. 
Electrodeposition for all electrolytic bath formulations was performed at fixed charge quantity of $540 \mathrm{C}$. Each bath formulation produced unique zinc electrodeposits as indicated by the nitrogen physisorption measurement (Table 1). This is the key attribute of electrodeposition technique. Table 2 highlights the zinc electrodeposits mass gain from each bath formulation. Although the quantity of $\mathrm{NH}_{4} \mathrm{Cl}$ supporting electrolyte was varied from zero until $4 \mathrm{M}$, the variation in the mass gain was not significant i.e. less than $1 \%$. Yet, the effect of quality of electrodeposits on zinc-air cell discharge capacity in particular, was substantial as displayed in Fig. 4. On the other hand, the variation in the limiting current was less prominent than the discharge capacity.

Table 2: Zinc electrodeposits mass gain from all electrolytic bath formulations.

\begin{tabular}{|c|c|}
\hline $\begin{array}{c}\text { Bath Composition }-\mathrm{NH}_{4} \mathrm{Cl} \text { Content } \\
(\mathrm{M})\end{array}$ & $\begin{array}{c}\text { Zinc electrodeposits mass gain } \\
(\mathrm{g})\end{array}$ \\
\hline 0 & 0.1846 \\
\hline 1 & 0.1837 \\
\hline 2 & 0.1832 \\
\hline 3 & 0.1848 \\
\hline 4 & 0.1832 \\
\hline
\end{tabular}

\section{CONCLUSION}

High surface area and porous zinc anode were prepared through electrodeposition from an acidic $\mathrm{ZnCl}_{2}-\mathrm{NH}_{4} \mathrm{Cl}$ electrolytic bath formulation. The BET surface area of the electrodeposits was in excess of $330 \mathrm{~m}^{2} \mathrm{~g}^{-1}$ and the electrode porosity was at least $60 \%$. Zinc-air microbattery measured $1 \mathrm{~cm}^{2}$ area $\mathrm{x} c a .305 \mu \mathrm{m}$ thick, utilizing the electrodeposited zinc anode, was able to deliver a maximum limiting current density of 55 $\mathrm{mA} \mathrm{cm}{ }^{-2}$. It produced an optimum discharge capacity of $34.5 \mathrm{mAh}$ rated at $20 \mathrm{~mA}$.

\section{ACKNOWLEDGEMENT}

The International Islamic University Malaysia funded this project through the Research Matching Grant Scheme (RMGS 09-09). The authors gratefully acknowledge the financial support.

\section{REFERENCES}

[1] C.N. Panagopoulos, K.G. Georgarakis and S. Petroutzakou, "Sliding wear behaviours of zinc-cobalt alloy electrodeposits". J. Mater. Process. Technol., 160, 234-244, 2006.

[2] M. Paunovic and M. Schlesinger, Fundamentals of Electrochemical Deposition, A WileyInterscience Publication, New York (1998).

[3] A. M. Alfantazi and D.B. Dreisinger, "The role of zinc and acid concentrations in the electrolyte on the zinc electrowinning from industrial sulfate-based electrolyte", J. Appl. Electrochem., 31, 641-646, 2001.

[4] R. Ramanauskas, "Structural factor in Zn alloy electrodeposit corrosion", Appl. Surf. Sci.153 53-64, 1999.

[5] Kim, B.N. Popov and K.S.Chen, "Synthesis and characterization of $\mathrm{MnO}_{2}$ based mixed oxides as supercapacitors", J. Electrochem. Soc., 150, 1505, 2003.

[6] B. Veeraraghavan, B. Haran, S. Prabu and B. Popov, "Corrosion protection of steel using non-anomalous Ni-Zn-P alloys", J. Elctrochem. Soc., 150, B131, 2003. 
IIUM Engineering Journal, Vol. 12, No. 5, 2011: Special Issue on Science and Ethics in Engineering Nor Hairin et al.

[7] C. Chi-Chung Hu and C. Yuan Chang, "Anodic stripping of zinc deposits for aqueous batteries: Effects of anions, additives, current densities, and plating modes", Mater. Chem. Phys., 86, 195-203, 2004.

[8] I. Zouari and F. Lapicque, "An electrochemical study of zinc deposition in a sulfate medium", Electrochim. Acta, 37, 439-446, 1992.

[9] Southampton Electrochemistry Group, Instrumental Methods in Electrochemistry, Ellis Horwood Ltd., England (1993) pg.178.

[10] H. Saputra, R. Othman, A.G.E. Sutjipto and R. Muhida, "MCM-41 as a new separator material for electrochemical cell: Application in zinc-air system", J. Mem. Sci., 367, 152$157,2011$.

[11] R. Othman, A.H. Yahaya and A.K. Arof, "Zinc-air cell employing porous zinc electrode fabricated from zinc-graphite-natural biodegradable polymer paste", J. Applied Electrochem, no 32, 1347-1353, 2002.

[12] S.F. Bender, J. W. Cretzmeyer and T.F. Reise in: Handbook of Batteries, Linden (Editor) 2nd Ed., McGraw-Hill, Inc (1995). 